\title{
Ho Chi Minh Stock Exchange Market: Operations and Efficiency
}

\author{
Van Nguyen Hong $\operatorname{Tran}^{1}$ \\ Hamid R Seddighi ${ }^{2}$ \\ 'Sunderland Business School, University of Sunderland, Sunderland, The UK. \\ Email:vantrans10@gmail.com Tel: (+84)935877155. \\ 'Email: hamid.seddighi@sunderland.ac.uk Tel: (+44)1915153109
}

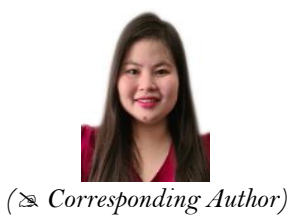

Abstract

This paper presents an up-to-date account of market operations of the Ho Chi Minh Stock Exchange and examines its informational efficiency in recent years. The daily closing prices and rates of return of the Vietnam (VN) Index - the major market index of the Ho Chi Minh Stock Exchange (HOSE) - and ten stocks chosen from different sectors are employed, from January 2, 2018, to December 31, 2019, to investigate the random walk hypothesis of market efficiency using the Lo-MacKinlay variance ratio test and the Chow-Denning multiple variance ratio test. Our results show that the market index and individual sample stocks conform to the null hypothesis of a random walk type 3 model of a weak form market efficiency. The paper also presents the results of an event study to examine the semi-strong form market efficiency of the HOSE. The empirical results on this type indicate that there are significant abnormal returns and significant cumulative abnormal returns by trading the stocks around events. However, these results are inconsistent with the requirements of a semi-strong form market efficiency, and it thus appears that further improvements in the transmission of information and its speed within this market are needed to further improve the efficiency of this emerging market.

Keywords: Emerging stock markets, Market operation, Market efficiency, Ho Chi Minh stock exchange, Variance ratio test, Event study. JEL Classification: C12; G14.

Citation | Van Nguyen Hong Tran; Hamid R Seddighi (2021). Ho Chi Minh Stock Exchange Market: Operations and Efficiency. Asian Journal of Economics and Empirical Research, 8(1): 27-38. History:

Received: 4. February 2021

Revised: 8 March 2021

Accepted: 12 April 2021

Published: 31 May 2021

Licensed: This work is licensed under a Creative Commons

Attribution 3.0 License (cc) E E

Publisher: Asian Online Journal Publishing Group
Acknowledgement: Both authors contributed to the conception and design of the study.

Funding: This study received no specific financial support

Competing Interests: The authors declare that they have no conflict of interest.

Transparency: The authors confirm that the manuscript is an honest, accurate, and transparent account of the study was reported; that no vital features of the study have been omitted; and that any discrepancies from the study as planned have been explained.

Ethical: This study followed all ethical practices during writing.

\section{Contents}

1. Introduction to Ho Chi Minh Stock Exchange and its Market Operations............................................................. 28

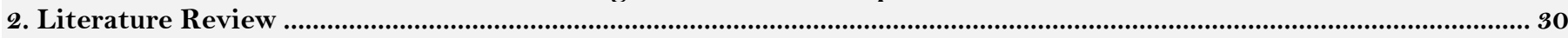

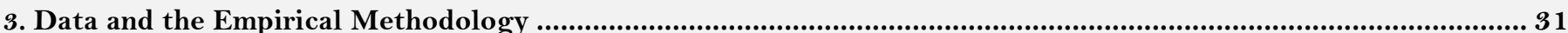

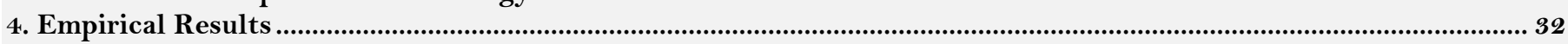

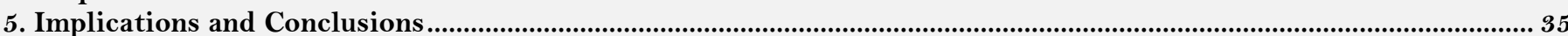

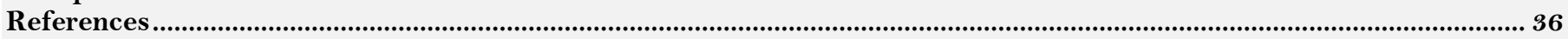




\section{Contribution of this paper to the literature}

This paper presents an up-to-date account of market operations of the Ho Chi Minh Stock Exchange and examines its informational efficiency in recent years.

\section{Introduction to Ho Chi Minh Stock Exchange and its Market Operations}

Vietnam's stock exchange markets are currently some of the most dynamic emerging stock markets in Asia (Pham, Nguyen, \& Vo, 2018). Ho Chi Minh Stock Exchange (HOSE) and Hanoi Stock Exchange (HNX) are key platforms for trading listed stocks in Vietnam (Huong \& Thuy, 2016). The HOSE is Vietnam's largest stock exchange, and it is the main market for trading stocks of large corporations. Since the initial milestones of establishing the Vietnamese stock market, there has been significant enhancement and development of this stock market. The government has focused on regaining trust in the market and its operations, particularly since the global financial crisis in 2010. Restructuring the securities market has been a primary strategic project of the Vietnamese government and the Ministry of Finance since 2012 (The Prime Minister, 2012).

From 2000 to 2019, the listed value on the HOSE jumped by VND 883,670 billion (see Figure 1). The market liquidity in 2019 remained stable. The average trading volume per session in 2019 was about 182.5 million shares, which is equivalent to an average trading value of VND 4,128 billion per session (Ho Chi Minh Stock Exchange, 2019). Market capitalization on the HOSE in 2019 peaked at nearly VND 3.28 trillion, which was over twice the market capitalization at the HOSE in 2016 (see Figure 1). The market capitalization at the HOSE accounted for more than $95 \%$ of the equity market capitalization nationwide.

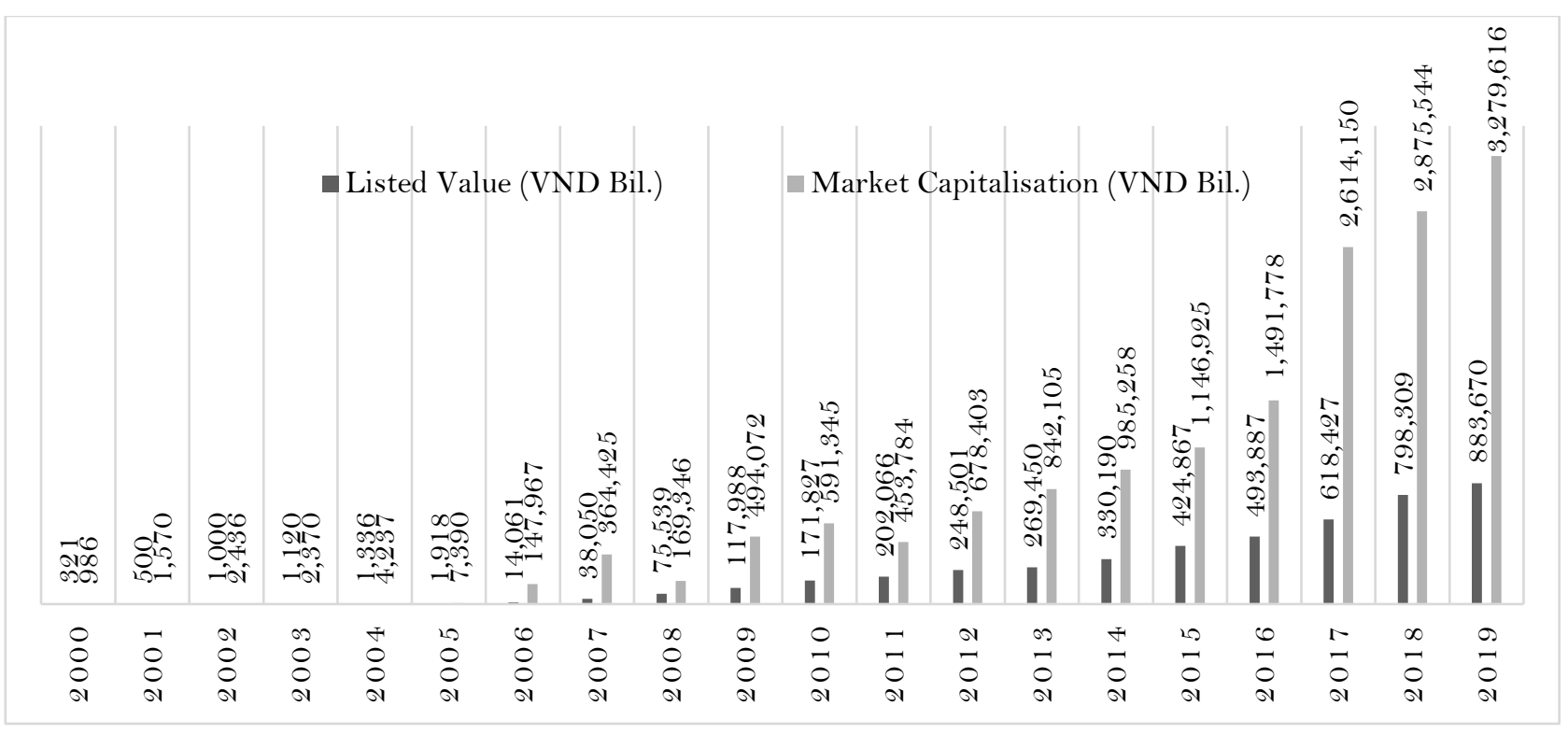

Figure 1. Listed values and mark
Source: Ho Chi Minh Stock Exchange (2019).

The market capitalization at the HOSE in 2018 was 2.87 , which is equivalent to nearly $52 \%$ of the gross domestic product (GDP) of Vietnam (Ho Chi Minh Stock Exchange, 2018) (see Figure 2). This was slightly more than the ratios of Indonesia and China in the same year but far from the levels reported in the Philippines, Malaysia, and Thailand (The World Bank, 2019). The performance of HOSE could be explained by abundant liquidity and positive market expectations of the state-owned enterprise equitization process (The World Bank, 2019). The market capitalization at the HOSE in 2019 was equivalent to nearly 54\% of Vietnam's GDP in 2019, which rose by $2 \%$ compared to the market capitalization at the HOSE in the previous year (Ho Chi Minh Stock Exchange, 2019).

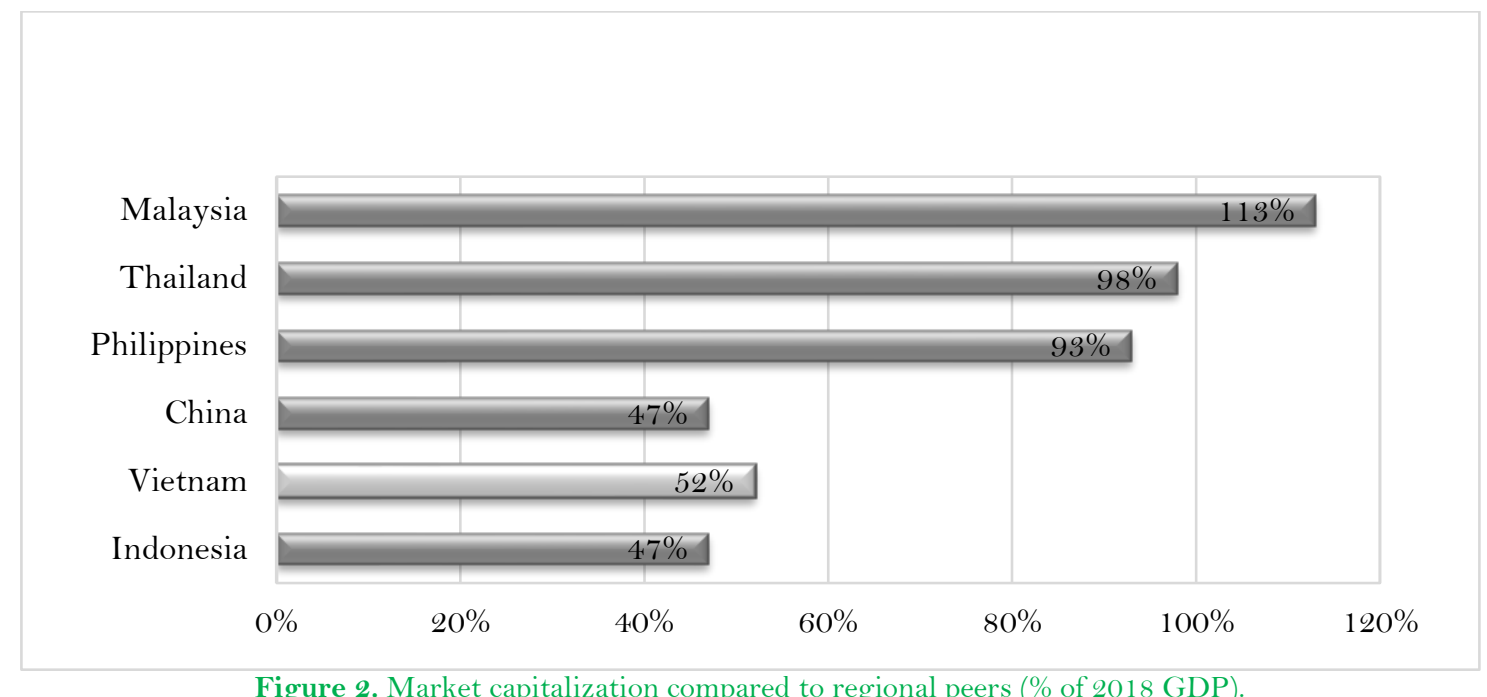

Source: The World Bank (2019).

Further, the market liquidity of the Vietnamese stock market was compared to regional peers (see Figure 3). The Vietnamese stock market was more active with a moderate turnover ratio of $40 \%$, which was in the midrange of the ratios obtained by the other frontiers and emerging markets in the region (The World Bank, 2019). 


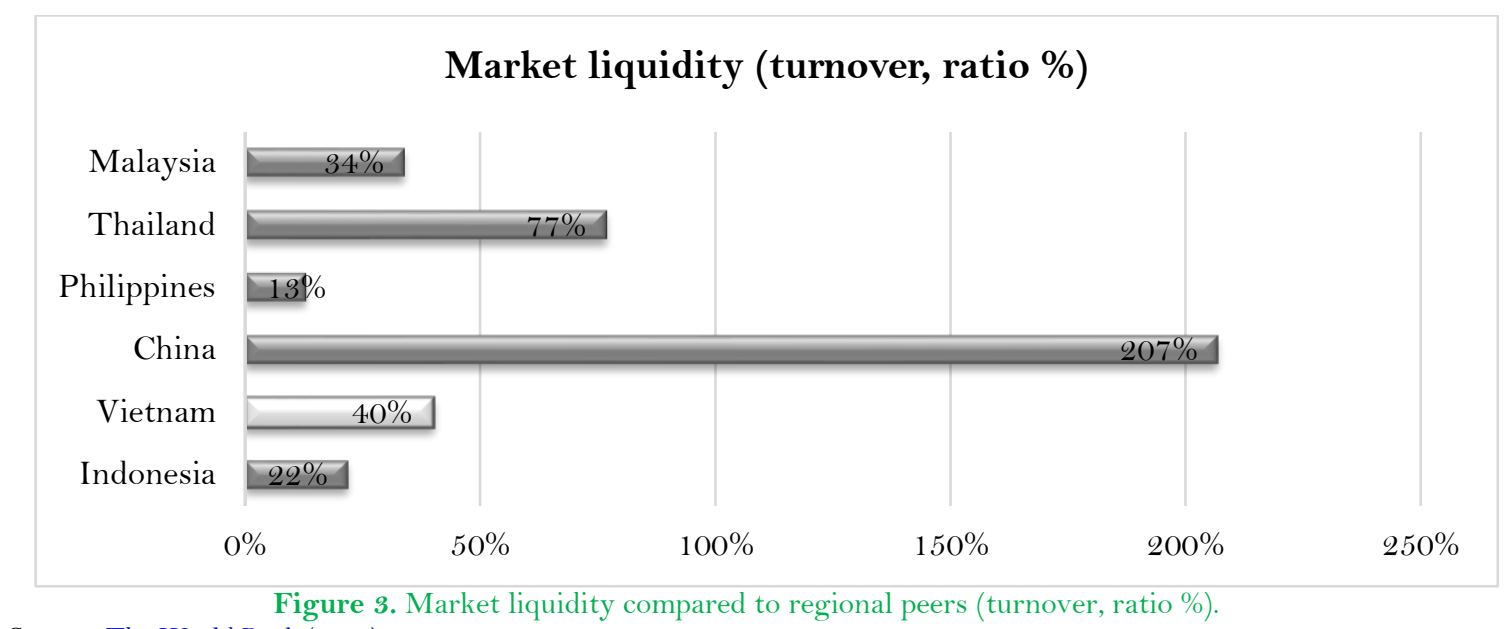

Source: The World Bank (2019).

In 2019, the price-to-earnings ratio $(\mathrm{P} / \mathrm{E})$ of the $\mathrm{VN}$ Index was 16.5 (see Table 1). Compared with the $\mathrm{P} / \mathrm{E}$ of other peer markets in Southeast Asia, the $\mathrm{P} / \mathrm{E}$ of the $\mathrm{VN}$ Index was the lowest and below the average $\mathrm{P} / \mathrm{E}$ of 19.12. Nonetheless, regarding the economic growth potential using OECD's GDP growth forecast for the period from 2019 to 2023, Vietnam is one of the economies which was predicted to obtain the greatest growth rate. Thus, the HOSE is expected to achieve a positive growth in the future to gradually narrow the gap to the other regional markets.

Table 1. Price-to-earnings (P/E) ratios of the VN Index and other indices in Southeast Asia.

\begin{tabular}{l|l|c|c|c}
\hline Market Index & Country & Expected GDP 2019-2023 (\%) & P/E & P/E forward 1 year \\
\hline VN Index & Vietnam & 6.5 & 16.5 & 16.8 \\
\hline PCOMP Index & Philippines & 3.7 & 19.4 & 16.7 \\
\hline SET Index & Thailand & 6.6 & 18.7 & 20.1 \\
\hline FBMKLCI Index & Malaysia & 5.2 & 21.2 & 21.9 \\
\hline JCI Index & Indonesia & 4.6 & 19.8 & 19 \\
\hline Average & 5.32 & 19.12 & 18.9 \\
\hline
\end{tabular}

Source: KB Securities Vietnam (2019); OECD (2019).

The correlations between return on equity $(\mathrm{ROE})$ and price-to-book values $(\mathrm{P} / \mathrm{B})$ of Asian countries are presented in Figure 4. The VN Index had a high ROE and a high P/B index compared to the ratios of other Asian countries. Furthermore, Vietnam became Southeast Asia's best-performing stock market in 2019 with a $12 \%$ gain for the VN Index on the HOSE (Preiss, 2019). Vietnam was the third-best performing market in the world over the past five years (Preiss, 2019). This provides positive growth potential for the market in the future.

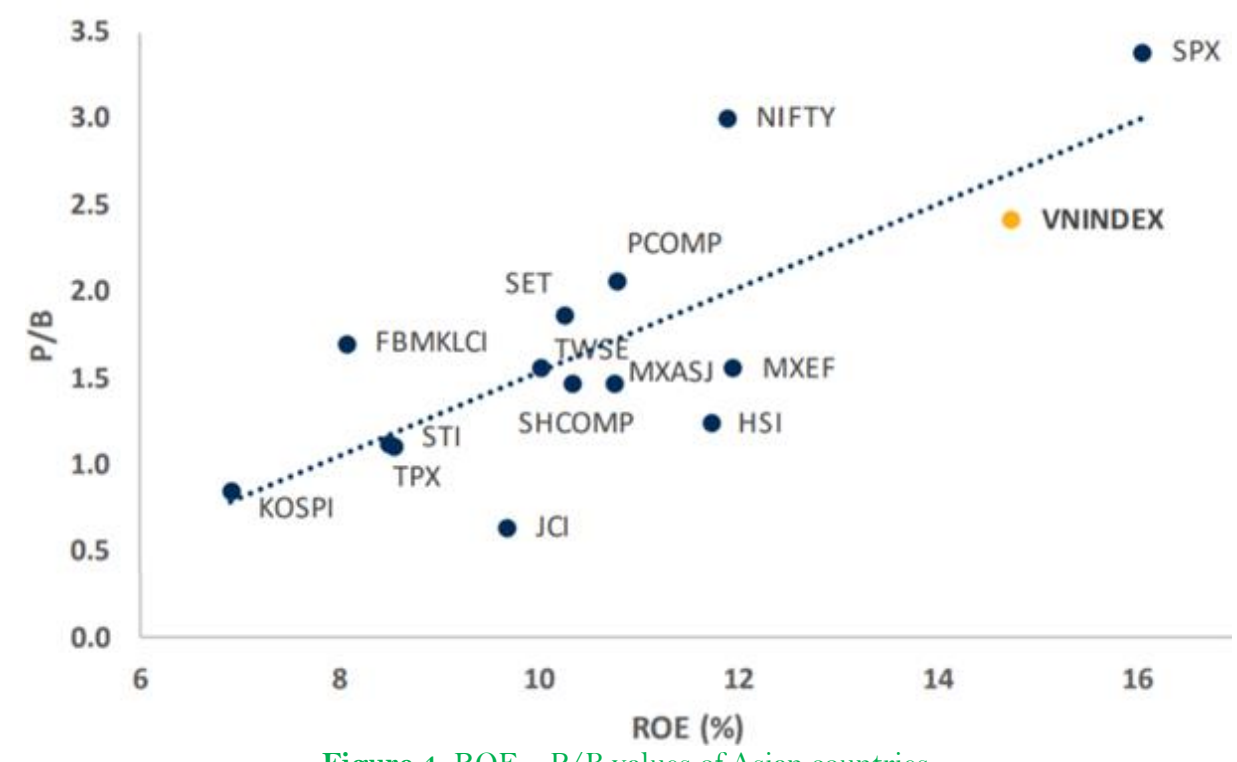

Source: KB Securities Vietnam (2019).

As of December 31, 2019, there were 378 listed company stocks on the HOSE; the ten major sectors on the HOSE are energy, materials, industrials, consumer discretionary, consumer staples, health care, financial, real estate, utilities and information technology. Article 6 of Decree No.39/2018/ND-CP states that classifications of enterprises could depend on the number of employees participating in social insurance and the total annual revenue or the total capital of enterprises (The Government, 2018). Accordingly, 100\% of companies listed on the HOSE were large companies (see Figure 5). 


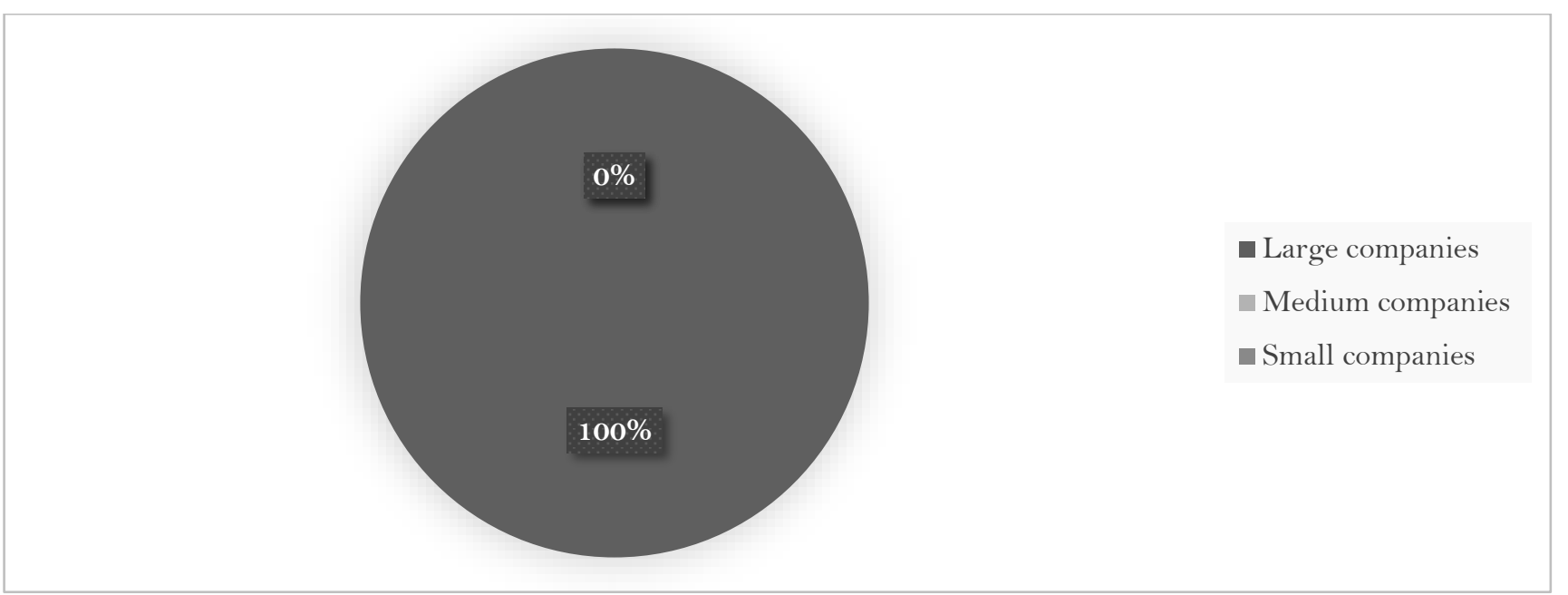

Figure 5. Classifications of companies listed on the HOSE based on company size.

According to Article 4 of the Law on Enterprises No. 68/2014/QH13, state-owned enterprises are redefined as enterprises in which 100\% of the charter capital is held by the State (The National Assembly, 2014). Based on the current law, 100\% of companies listed on the HOSE and the HNX are not state-owned companies. However, under Article 141 of the Law on Enterprises No. 68/2014/QH13, conditions for conducting the general meeting of shareholders were listed. It is stated that the general meeting of shareholders shall be conducted when the number of attending shareholders represents at least $51 \%$ of the total number of votes. Additionally, resolutions are passed if the number of shareholders represents at least $65 \%$ of the total votes and all attending shareholders agree. It is of concern whether the proportion of state stockholders in the listed companies is equal to or greater than $51 \%$ (see Figure 6). Currently, the State owns at least $51 \%$ of the outstanding stocks of $20 \%$ of the listed companies on the HOSE.

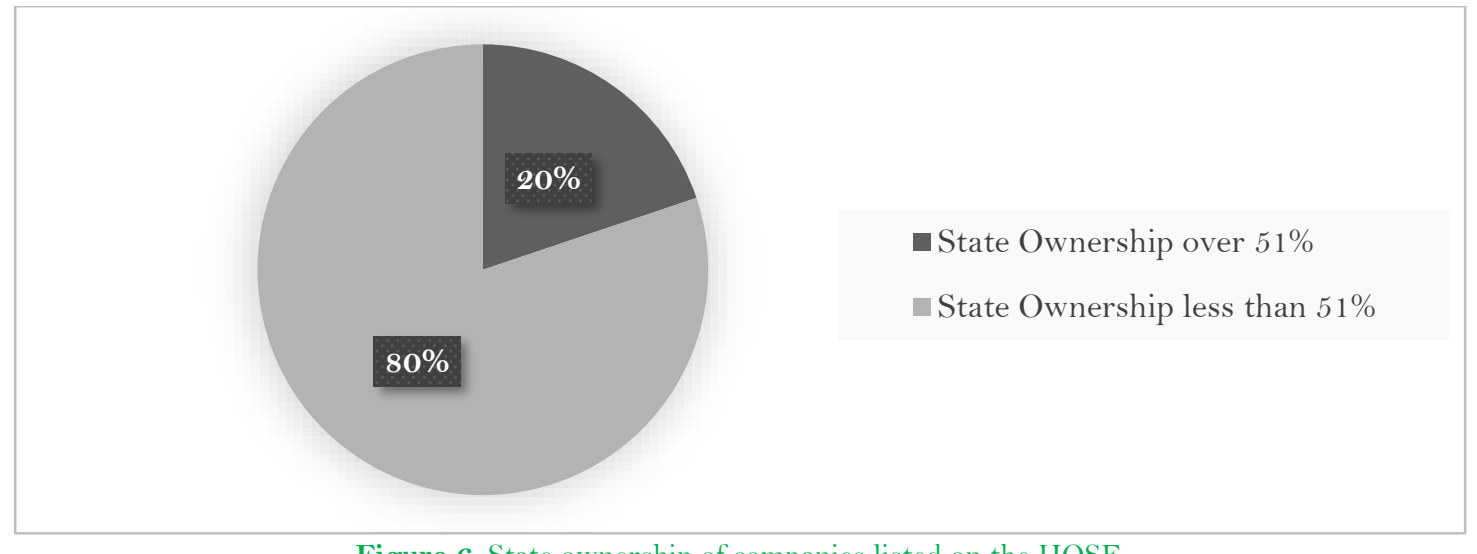

Figure 6. State ownership of companies listed on the HOSE.

\section{Literature Review}

There has been a considerable growth in demand for investment funds in Vietnam, resulting in significant market activities on the Vietnamese stock exchanges in terms of both market capitalization and liquidity (Gupta, Yang, \& Basu, 2014; Vo \& Truong, 2018). The new listings of companies and participation of foreign investors have accelerated the HOSE market's development in recent years (Vo \& Truong, 2018). Despite the rapid rise in the market activities in recent years, there is a limited number of studies on the key emerging market operations and efficiency.

Dong Loc, Lanjouw, \& Lensink (2010) used weekly price series of the VN Index and the five oldest stocks on the stock exchange to test for market efficiency. The results obtained from the autocorrelation tests, run tests and variance ratio tests all failed to support the random walk hypothesis of a weak form market efficiency. These findings were consistent with those of Do, Le, \& Nguyen (2015), Luu, Pham, \& Pham (2016) and Shaik \& Maheswaran (2017), whose detailed statistical investigations showed that the Vietnamese stock market is not weak form efficient. However, Phan \& Zhou (2014) and Gupta et al. (2014) indicated a gradual improvement towards market efficiency, although, overall, the Vietnamese stock market has remained inefficient for more than ten years. Results under the assumption of homoscedastic and heteroscedastic increments in these papers provided enough evidence to accept the random walk hypothesis in the third sub-period, which implies that the Vietnamese stock market was weak form efficient after the crisis.

Tran \& Mai (2015) investigated the effects of dividend announcements on share prices in the Vietnamese stock market using an event study method. The dataset included closing prices and adjusted closing prices of 233 companies listed on the HOSE with a total of 979 dividend announcements between 2008 and 2014 (Tran \& Mai, 2015). There were three groups of dividend announcements in the study - dividend increases, dividend decreases and no change. It was indicated that the mean and median values of abnormal returns from day -2 to day -1 in the dividend increase cluster were significantly positive. Moreover, the abnormal trading volume was significantly different from zero from day 0 to day +5 in these three groups. This provided strong statistical evidence of information leakage or insider trading before the announcement date and the low transparency level of the stock market (Tran \& Mai, 2015). Therefore, the market was not semi-strong efficient.

The empirical research of Tran, Nguyen, \& Pham (2016) appraised semi-strong form efficiency in the Vietnamese stock market by analyzing the market reaction to dividend and earnings announcements. It involved 
247 listed companies on the HOSE from 2014 to 2015 (Tran et al., 2016). The daily stock prices of the VN Index and each firm were used for 20 days around the publishing day from the HOSE database, and the data consisted of announcements of dividends and quarterly earnings of the companies. As a result, there was an insignificant reaction to the announcement day and in few days around it. Additionally, there were significant abnormal returns within 20 trading days surrounding the date of dividend and earnings announcements. The stock prices did not promptly and adequately reflect the new information and these announcements had a significant impact on the stock prices in the event window of 20 days. In other words, the evidence did not support the requirements of a semi-strong form in the Vietnamese stock market (Tran et al., 2016). Appendix 1 presents a summary of empirical studies related to the Vietnamese stock market.

It is evident from this brief review of recent studies that there are clear gaps in the literature in two key areas. First, there is little empirical evidence available on the status of this market efficiency after the changes of regulations in 2012. Second, there appears to be little up to date information regarding this market's operations and activities in recent years. This paper aims to fill these gaps, and its purpose is twofold:

1. To provide an up-to-date account of the recent operations of the Ho Chi Minh Stock Exchange (HOSE) market under the new market regulations since 2012 .

2. To test the efficiency of this market based on the random walk model and event study using recent data relating to market activities after the introduction of the new market regulations in 2012.

The first point is provided in the first section of the introduction to the Ho Chi Minh Stock Exchange and its market operations, and the second is fulfilled in the following sections. The remainder of the work is organized as follows: Section 3 discusses the data and the empirical methodology of this study; Section 4 discusses the empirical results of the HOSE market efficiency; and Section 5 discusses the implications and conclusions of the study.

\section{Data and the Empirical Methodology}

To fulfill the gap and meet the research objectives, the study examines the overall stock price behavior of the HOSE stock price index (VN Index) and the stock price behavior of ten of its listed companies which were selected randomly from ten sectors. These are: An Phat Bioplastics Joint Stock Company (AAA) from the materials sector; Binh Duong Water Environment Joint Stock Company (BWE) from the utilities sector; BIDV Securities Joint Stock Company (BSI) from the financial sector; Dong A Plastic Group Joint Stock Company (DAG) from industrials; Digiworld Corp (DGW) from the information technology sector; Binh Dinh Pharmaceutical and Medical Equipment Joint Stock Company (DBD) from the health care sector; Danang Rubber Joint Stock Company (DRC) from the consumer discretionary sector; Vietnam National Petroleum Group (PLX) from the energy sector; Saigon Beer - Alcohol - Beverage Corporation (SAB) from the consumer staples sector; and Sai Gon Thuong Tin Real Estate Joint Stock Company (SCR) from the real estate sector.

Daily stock prices for the VN index and the above listed companies were collected for the period from January 2, 2018, to December 31, 2019, generating 498 observations on the market index and each of the selected stocks. The testing procedures involve the following steps: (1) Variance ratio tests under the independently and identically distributed assumptions are performed without bias correction to test the homoscedastic random walk model; (2) Multiple variance ratio tests are performed by repeating the previous procedure but allowing for heteroscedasticity in the data and using bootstrapping to illustrate the statistical significance. Wright's rank variance ratio test was also conducted to support the tests in step 1 and step 2. Wright (2000) proposed the variance ratio tests that do not rely on asymptotic approximations and are done under homoscedasticity; (3) If the null hypothesis of a random walk model is not rejected in ALL cases, the study then performs an event study analysis to test the semi-strong market form efficiency.

Combining all sample data, the study uses 5478 observations. We start by implementing tests of random walks and weak form market efficiency. Then, semi-strong form efficiency is examined if the requirements of a weak form market efficiency are met in all sample cases.

\subsection{Weak Form Tests}

To appraise the market efficiency, the random walk model is employed and is defined as:

$$
\begin{gathered}
p_{t}=\mu+p_{t-1}+\varepsilon_{t} \\
\text { or } \Delta p_{t}=y_{t}=p_{t}-p_{t-1}=\mu+\varepsilon_{t}
\end{gathered}
$$

where:

$\Delta p_{t}\left(y_{t}\right)$ is the continuously pounded rate of return for a stock at time $t$.

$p_{t}$ and $p_{t-1}$ are the natural logarithms of the stock prices at time $t$ and $t-1$.

$\mu$ is an unknown drift parameter.

$\varepsilon_{t}$ is the random disturbance term.

Equation 1 is used to examine whether the daily stock returns/movements are randomly distributed. The random walk implies uncorrelated residuals and hence uncorrelated returns $\left(\Delta p_{t}\right)$.

The hypotheses to be tested are:

$H_{o:}$ Vietnamese market indices and stock prices follow a random walk.

$H_{1}$ : Vietnamese market indices and stock prices do not follow a random walk.

Campbell, Lo, \& MacKinlay (1997) classified three types of random walk. Random walk type 1 (RW1) allows for homoscedasticity and it is known as the homoscedastic Random Walk Hypothesis. Random walk type 2 (RW2) and random walk type 3 (RW3) allow for heteroscedasticity. RW2 is used to test the assumption of unconditional heteroscedasticity in the random disturbances. RW3 is more general, and it is used to examine the assumption of the conditional heteroscedastic Random Walk Hypothesis. Additionally, RW1 is considered as a special case of RW2, and RW1 and RW2 are special cases of RW3. RW1 is the strongest form of random walk, and RW3 is the weakest form of random walk (Campbell et al., 1997). Thus, this study employs tests to examine RW1 and RW3. The statistical tests are conducted using EViews 10.

Regarding the decision-making process used in this study, in order for the market to meet the requirements of RW 1 or RW3, the results obtained from these tests, in all cases, are required to show that the null hypothesis is 
not rejected. The single variance ratio test by Lo \& MacKinlay (1988) and the multiple variance ratio test by Chow \& Denning (1993) are two key tests, while other tests are also considered as supporting tests in this study. The single variance ratio test by Lo \& MacKinlay (1988) is employed to test the individual null hypothesis of a random walk, while the multiple variance ratio test by Chow \& Denning (1993) is used to examine the joint null hypothesis. This work requires all results of the Lo \& MacKinlay tests and the Chow \& Denning tests to not be rejected under the null hypothesis of RW1 or RW3 if the market meets the requirements of RW1 or RW3.

\subsection{Semi-Strong Form Tests}

If the results of the above tests indicate that the null hypothesis is not rejected in all sample cases, tests of semistrong form market efficiency might be conducted via an event study. The event study gauges the effects of a specific event on stockholder wealth by examining an abnormal movement of stock prices around the event (Mann \& Babbar, 2017). The abnormal returns refer to the difference between the actual returns after an event and the normal returns that a firm would have gained without the effects of such an event (Eryigit \& Eryigit, 2019; Mann $\&$ Babbar, 2017). The event study method has a variety of applications and contributions in accounting and finance research (MacKinlay, 1997).

The most popular model to estimate normal behavior is a regression based on the actual return of the stock and the actual return of the market index or industry index (Benninga, 2014). The paper collects and analyzes the stock daily closing prices and rates of returns of the VN Index - the major market index in the HOSE, and DRC and BWE - two listed companies randomly selected from the HOSE. BWE is one of the newly listed company stocks, while DRC is one of the existing listed company stocks.

This method has been used to investigate several specific firms and economy-wide events (Benninga, 2014). In this study, three event days on which there were huge daily changes in the VN Index closing prices and its rates of returns were randomly chosen. The information is summarized in Table 2.

Table 2. Chosen events in event study based on VN Index.

\begin{tabular}{c|c|c|l}
\hline No & Date & Daily returns & Event \\
\hline 1 & $05 / 02 / 18$ & $-5.10 \%$ & $\begin{array}{l}\text { Information from the Chairman of the State Securities Commission related } \\
\text { to the roadmap for applying an increase of the initial margin and impact of } \\
\text { volatility of the US stock market impacted investor sentiment. }\end{array}$ \\
\hline 2 & $03 / 07 / 18$ & $-4.34 \%$ & $\begin{array}{l}\text { Fears of an escalating trade war between the US and China and the } \\
\text { problems of climbing exchange rates and lowering expected profits of listed } \\
\text { companies. }\end{array}$ \\
\hline 3 & $11 / 10 / 18$ & $-4.84 \%$ & $\begin{array}{l}\text { Selloffs of European and American stocks due to concerns about rising US } \\
\text { government bond yields and psychological effects of the escalating trade } \\
\text { war on investors. }\end{array}$ \\
\hline
\end{tabular}

With randomly chosen securities and event dates, there should be no abnormal performance on average if the stock market has semi-strong form efficiency (Brown \& Warner, 1985). A parametric t-test is utilized to evaluate whether abnormal returns (ARs) and cumulative abnormal returns (CARs) are significantly different from zero. The parametric t-test in this work is performed based on the studies of Brown \& Warner (1985); MacKinlay (1997) and Eryigit \& Eryigit (2019).

The abnormal return (AR) for a stock $i$ on day $t$ is calculated as follows:

$A R_{i t}=y_{i t}-\left(\alpha_{i}+\beta_{i} y_{m t}\right)$

Where: $y_{i t}$ represents actual stock return on day t;

$\alpha_{i}+\beta_{i} y_{m t}$ represents returns expected by the $\alpha, \beta$ and corresponding market return of the stock.

Equation 2 investigates the abnormal returns $\left(A R_{i}\right)$ using the market return model. It assumes a linear relationship between market return, individual asset return, and constant variance.

The cumulative abnormal return (CAR) for a stock $i$ on day $t$ is calculated as:

$C A R_{i, t}=C A R_{i,-t}+A R_{i t}$

or $C A R_{i,\left(\tau_{2}, \tau_{3}\right)}=\sum_{t=\tau_{2}}^{\tau_{3}} A R_{i, t}$

According to MacKinlay (1997), abnormal returns need to be cumulated to analyze the general effect of the event. Abnormal returns are cumulated based on time as per Equation 3. Cumulating based on time reflects cumulative abnormal returns in the event window.

The hypotheses to be tested include:

$H_{0:}$ The abnormal returns (ARs) and cumulative abnormal returns (CARs) are close to zero.

$H_{1}$ : The abnormal returns (ARs) and cumulative abnormal returns (CARs) are greatly different from zero.

The parametric t-test in this study is conducted in Excel. The alternative hypotheses indicate that ARs and CARs could be less or more than zero, so the tests are two-tailed. With a significant level of $5 \%, \mathrm{H}_{0}$ will not be rejected if the calculated t-value belongs to the range of -1.96-1.96.

Within this framework, the HOSE would be considered to be semi-strong form efficient if the null hypothesis that ARs and CARs are close to zero is not rejected at a prespecified level of significance.

\section{Empirical Results \\ 4.1. Weak form Market Efficiency}

The variance ratio tests are conducted using the EViews statistical package to examine the random walk model and martingale hypothesis for the daily return data of the market index and ten stock prices from January 2, 2018, to December 31, 2019. The default settings used in this study to test the specified lists are 2, 5, 10, 20, and 30 to investigate the data for the periods of 2 working days, 5 working days, 10 working days, 20 working days and 30 working days. The detailed statistical results of the VN Index are provided in Appendix 2. The procedure is also carried out on the data of the chosen listed companies on the HOSE. Table 3 summarizes the results of the variance 
ratio tests on the logarithm of daily closing prices of the VN Index and the listed companies on the HOSE. The statistical results of the joint null hypothesis tests are presented in Appendix 3.

Table 3. Statistical results of the VN Index and ten companies listed on the HOSF

\begin{tabular}{|c|c|c|c|c|c|c|c|c|c|}
\hline \multirow{3}{*}{ No. } & \multirow{3}{*}{$\begin{array}{l}\text { Market } \\
\text { index/ } \\
\text { Company } \\
\text { Code }\end{array}$} & \multicolumn{3}{|c|}{ Homoscedastic Random Walk Hypothesis } & \multicolumn{2}{|c|}{$\begin{array}{l}\text { Conditional Heteroscedastic } \\
\text { Random Walk Hypothesis }\end{array}$} & \multicolumn{3}{|c|}{ Wright's Rank Variance Ratio Tests } \\
\hline & & \multirow{2}{*}{$\begin{array}{l}\text { Individual } \\
\text { Null } \\
\text { Hypothesis } \\
\text { Lo \& } \\
\text { MacKinlay } \\
\text { Test }\end{array}$} & \multicolumn{2}{|c|}{ Joint Null Hypothesis } & \multirow{2}{*}{$\begin{array}{l}\text { Individual } \\
\text { Null } \\
\text { Hypothesis } \\
\text { Lo \& } \\
\text { MacKinlay } \\
\text { Test }\end{array}$} & \multirow{2}{*}{$\begin{array}{l}\begin{array}{l}\text { Joint Null } \\
\text { Hypothesis }\end{array} \\
\text { Chow \& } \\
\text { Denning Test }\end{array}$} & \multirow{2}{*}{$\begin{array}{l}\text { Individual } \\
\text { Null } \\
\text { Hypothesis } \\
\text { Lo \& } \\
\text { MacKinlay } \\
\text { Test }\end{array}$} & \multicolumn{2}{|c|}{ Joint Null Hypothesis } \\
\hline & & & $\begin{array}{l}\text { Chow \& } \\
\text { Denning } \\
\text { Test }\end{array}$ & $\begin{array}{l}\text { Wald-type } \\
\text { Test }\end{array}$ & & & & $\begin{array}{l}\text { Chow \& } \\
\text { Denning Test }\end{array}$ & $\begin{array}{l}\text { Wald-type } \\
\text { Test }\end{array}$ \\
\hline 1 & VN Index & Rejected & Rejected & Rejected & Not rejected & Not rejected & Not rejected & Not rejected & Rejected \\
\hline 2 & AAA & Not rejected & Not rejected & Rejected & Not rejected & Not rejected & Not rejected & Not rejected & Rejected \\
\hline 3 & BWE & Not rejected & Not rejected & Rejected & Not rejected & Not rejected & Not rejected & Not rejected & Rejected \\
\hline 4 & BSI & Not rejected & Not rejected & Rejected & Not rejected & Not rejected & Not rejected & Not rejected & Rejected \\
\hline 5 & DAG & Not rejected & Not rejected & Rejected & Not rejected & Not rejected & Not rejected & Not rejected & Rejected \\
\hline 6 & DGW & Not rejected & Not rejected & Not rejected & Not rejected & Not rejected & Not rejected & Not rejected & Rejected \\
\hline 7 & DBD & Not rejected & Not rejected & Rejected & Not rejected & Not rejected & Not rejected & Not rejected & Rejected \\
\hline 8 & DRC & Not rejected & Not rejected & Rejected & Not rejected & Not rejected & Not rejected & Not rejected & Rejected \\
\hline 9 & PLX & Not rejected & Not rejected & Rejected & Not rejected & Not rejected & Not rejected & Not rejected & Rejected \\
\hline 10 & $\mathrm{SAB}$ & Not rejected & Not rejected & Rejected & Not rejected & Not rejected & Rejected & Rejected & Rejected \\
\hline 11 & SCR & Not rejected & Not rejected & Rejected & Not rejected & Not rejected & Not rejected & Not rejected & Rejected \\
\hline \multicolumn{2}{|c|}{$\begin{array}{l}\text { No. of rejected } \\
\text { nulls }\end{array}$} & 1 & 1 & 10 & o & o & 1 & 1 & 11 \\
\hline
\end{tabular}

RW1 is the strictest form of random walk. In RW1, there are independently and identically distributed increments with a mean of $\mathrm{O}$ and a variance of $\sigma^{2}$. When a stock market is weak form efficient, the market indices or stock prices of any listed company should meet the requirements of weak form efficiency. The results for the VN Index from the homoscedastic random walk model test consistently reject the joint and individual null hypotheses of a random walk under homoscedasticity based on the Chow-Denning and Lo-MacKinlay tests. Further, the Richardson-Smith Wald test statistic does not accept the joint null hypothesis in ten cases. Therefore, it could strongly reject the null hypothesis of RW1 under homoscedasticity.

The rejection of the random walk null hypothesis is supported by Wright's rank variance ratio test, which is also used to test the RW1 model. A rejection of the joint null hypothesis in the case of SAB leads to the joint null hypothesis of a random walk also being rejected on the HOSE based on the Chow-Denning test. Moreover, there is a rejection of the individual null hypothesis in the case of SAB based on the Lo-MacKinlay test, so the individual null hypothesis of a random walk is not accepted on the HOSE. Additionally, the Richardson-Smith Wald test statistic does not accept the joint null hypothesis in 11 cases. Subsequently, there is a strong rejection of the null hypothesis of RW1 based on the results of all tests carried out.

In terms of the multiple variance ratio test, all of the Chow-Denning maximum $|z|$ statistic values are less than the critical value of 1.96, and their corresponding p-values are all more than the significant value of 0.05. Moreover, in the individual tests, the variance ratio statistics are not significantly and statistically different from 1.0, all absolute values of the $\mathbf{z}$-statistic are less than the critical value of 1.96 and their appropriate bootstrap p-values are all greater than the $5 \%$ significance level. The joint null hypothesis and the individual null hypothesis of a martingale are not rejected under conditional heteroscedasticity. This indicates that the logarithm of the stock price series of the VN Index and the selected listed companies on the HOSE are almost certainly random and conform to the hypothesis of RW3. Therefore, the null hypothesis of a martingale could not be rejected on the logarithms of the VN Index and all chosen stocks on the HOSE at the $\%$ significance level. According to the martingale hypothesis, the expected returns and price changes projected on the basis of information fully reflected in the current price are zero, the stock price sequence will follow a martingale (Dong Loc et al., 2010). This intimates that there is no systematic price movement and it could lead to an effective linear forecasting rule in the market.

\subsection{Semi-Strong Form Market Efficiency}

The Ho Chi Minh Stock Exchange appears to meet the conditions of the weak form efficient market hypothesis, so the semi-strong form efficient hypothesis will be assessed. In this work, the shortest time gap between announcement dates of any two chosen events impacting the market indices and stocks on the HOSE is 70 days. Moreover, the estimation window is regarded as the period before the event, and the longest event window in this work is 21 days of $(-10,+10)$. Thus, in this study, the estimation window will be 35 days until the day before the event window $(-10 ;+10)$. In addition, there are two types of mistakes in a statistical hypothesis test (Stock \& Watson, 2015). In the study, the type I significance level is defined, and it is crucial to evaluate other smaller event windows to limit the possibility of a type II error occurring. Therefore, this research also considers other event windows $(-5 ;+5)$ and $(-1 ;+1)$ to understand the reaction of the stock prices to the information raised.

The abnormal returns (ARs) for DRC and BWE related to event 1 are provided in Table 4. On the event day, the ARs under the market-adjusted returns for DRC and BWE are $-2.463 \%$ and $-2.948 \%$, respectively. These values are statistically insignificant at the $5 \%$ significance level. However, on day -6 in the event window for BWE, there is a huge abnormal return of $6.375 \%$ and its corresponding t-statistic value is 1.991 . This is statistically significant at the $5 \%$ significance level, which implies that significant ARs could be gained six days before the event day by exploiting the relevant information leakage. This leads to the rejection of the null hypothesis that ARs are close to zero. 
Table 4. Event 1 - Abnormal Returns for DRC and BWE.

\begin{tabular}{|c|c|c|c|c|c|c|c|}
\hline \multicolumn{8}{|l|}{ EVENT 1} \\
\hline \multicolumn{4}{|l|}{ DRC } & \multicolumn{4}{|l|}{ BWE } \\
\hline $\begin{array}{c}\text { Date in event } \\
\text { study }\end{array}$ & AR & $\begin{array}{l}\text { t-statistics } \\
\text { of AR }\end{array}$ & Significance & $\begin{array}{c}\text { Date in } \\
\text { event study }\end{array}$ & AR & $\begin{array}{l}\text { t-statistics } \\
\text { of AR }\end{array}$ & Significance \\
\hline-10 & $-1.942 \%$ & -0.633 & $\mathrm{NO}$ & -10 & $1.418 \%$ & 0.443 & $\mathrm{NO}$ \\
\hline-9 & $-0.731 \%$ & -0.239 & $\mathrm{NO}$ & -9 & $0.020 \%$ & 0.006 & $\mathrm{NO}$ \\
\hline-8 & $-2.823 \%$ & -0.921 & $\mathrm{NO}$ & -8 & $-4.218 \%$ & -1.317 & $\mathrm{NO}$ \\
\hline-7 & $-5.069 \%$ & -1.653 & $\mathrm{NO}$ & -7 & $-1.430 \%$ & -0.446 & $\mathrm{NO}$ \\
\hline-6 & $3.099 \%$ & 1.011 & $\mathrm{NO}$ & -6 & $6.375 \%$ & 1.991 & YES \\
\hline-5 & $-0.096 \%$ & -0.031 & $\mathrm{NO}$ & -5 & $1.225 \%$ & 0.383 & $\mathrm{NO}$ \\
\hline-4 & $-1.230 \%$ & -0.401 & $\mathrm{NO}$ & -4 & $-0.031 \%$ & -0.010 & $\mathrm{NO}$ \\
\hline-3 & $-3.026 \%$ & -0.987 & $\mathrm{NO}$ & -3 & $-1.589 \%$ & -0.496 & $\mathrm{NO}$ \\
\hline-2 & $-1.046 \%$ & -0.341 & $\mathrm{NO}$ & -2 & $-0.068 \%$ & -0.021 & $\mathrm{NO}$ \\
\hline-1 & $0.090 \%$ & 0.029 & $\mathrm{NO}$ & -1 & $-1.231 \%$ & -0.384 & $\mathrm{NO}$ \\
\hline $\mathrm{O}$ & $-2.463 \%$ & -0.803 & $\mathrm{NO}$ & $\mathrm{O}$ & $-2.948 \%$ & -0.921 & $\mathrm{NO}$ \\
\hline 1 & $2.441 \%$ & 0.796 & $\mathrm{NO}$ & 1 & $0.150 \%$ & 0.047 & $\mathrm{NO}$ \\
\hline 2 & $-0.999 \%$ & -0.326 & $\mathrm{NO}$ & 2 & $1.594 \%$ & 0.498 & $\mathrm{NO}$ \\
\hline 3 & $0.159 \%$ & 0.052 & $\mathrm{NO}$ & 3 & $-0.415 \%$ & -0.129 & $\mathrm{NO}$ \\
\hline 4 & $-0.711 \%$ & -0.232 & $\mathrm{NO}$ & 4 & $0.395 \%$ & 0.123 & $\mathrm{NO}$ \\
\hline 5 & $1.550 \%$ & 0.506 & $\mathrm{NO}$ & 5 & $1.264 \%$ & 0.395 & $\mathrm{NO}$ \\
\hline 6 & $-1.139 \%$ & -0.372 & $\mathrm{NO}$ & 6 & $-1.444 \%$ & -0.451 & $\mathrm{NO}$ \\
\hline 7 & $-1.471 \%$ & -0.480 & $\mathrm{NO}$ & 7 & $-1.167 \%$ & -0.364 & $\mathrm{NO}$ \\
\hline 8 & $-2.512 \%$ & -0.819 & $\mathrm{NO}$ & 8 & $-0.788 \%$ & -0.246 & $\mathrm{NO}$ \\
\hline 9 & $-0.861 \%$ & -0.281 & $\mathrm{NO}$ & 9 & $0.713 \%$ & 0.223 & $\mathrm{NO}$ \\
\hline 10 & $-2.026 \%$ & -0.661 & $\mathrm{NO}$ & 10 & $1.127 \%$ & 0.352 & $\mathrm{NO}$ \\
\hline
\end{tabular}

Table 5. Event 2 - Abnormal Returns for DRC and BWE.

\begin{tabular}{|c|c|c|c|c|c|c|c|}
\hline \multicolumn{8}{|l|}{ EVENT 2} \\
\hline \multicolumn{4}{|l|}{ DRC } & \multicolumn{4}{|l|}{ BWE } \\
\hline $\begin{array}{c}\text { Date in } \\
\text { event study }\end{array}$ & AR & $\begin{array}{c}\text { t-statistics } \\
\text { of AR }\end{array}$ & Significance & $\begin{array}{c}\text { Date in event } \\
\text { study }\end{array}$ & AR & $\begin{array}{c}\text { t-statistics of } \\
\text { AR }\end{array}$ & Significance \\
\hline-10 & $8.835 \%$ & 1.178 & $\mathrm{NO}$ & -10 & $-1.928 \%$ & -0.655 & $\mathrm{NO}$ \\
\hline-9 & $6.328 \%$ & 0.844 & $\mathrm{NO}$ & -9 & $-2.951 \%$ & -1.002 & $\mathrm{NO}$ \\
\hline-8 & $5.324 \%$ & 0.710 & $\mathrm{NO}$ & -8 & $1.542 \%$ & 0.524 & $\mathrm{NO}$ \\
\hline-7 & $4.497 \%$ & 0.600 & $\mathrm{NO}$ & -7 & $7.599 \%$ & 2.58 & YES \\
\hline-6 & $5.155 \%$ & 0.687 & $\mathrm{NO}$ & -6 & $0.773 \%$ & 0.262 & $\mathrm{NO}$ \\
\hline-5 & $10.496 \%$ & 1.399 & $\mathrm{NO}$ & -5 & $-3.796 \%$ & -1.289 & $\mathrm{NO}$ \\
\hline-4 & $9.414 \%$ & 1.255 & $\mathrm{NO}$ & -4 & $0.318 \%$ & 0.108 & $\mathrm{NO}$ \\
\hline-3 & $8.820 \%$ & 1.176 & $\mathrm{NO}$ & -3 & $2.766 \%$ & 0.939 & $\mathrm{NO}$ \\
\hline-2 & $6.499 \%$ & 0.866 & $\mathrm{NO}$ & -2 & $0.801 \%$ & 0.272 & $\mathrm{NO}$ \\
\hline-1 & $6.353 \%$ & 0.847 & $\mathrm{NO}$ & -1 & $0.021 \%$ & 0.007 & $\mathrm{NO}$ \\
\hline $\mathrm{O}$ & $3.907 \%$ & 0.521 & $\mathrm{NO}$ & $\mathrm{O}$ & $0.838 \%$ & 0.284 & $\mathrm{NO}$ \\
\hline 1 & $0.421 \%$ & 0.056 & $\mathrm{NO}$ & 1 & $1.062 \%$ & 0.361 & $\mathrm{NO}$ \\
\hline 2 & $1.746 \%$ & 0.233 & $\mathrm{NO}$ & 2 & $0.951 \%$ & 0.323 & $\mathrm{NO}$ \\
\hline 3 & $-0.247 \%$ & -0.033 & $\mathrm{NO}$ & 3 & $-2.683 \%$ & -0.911 & $\mathrm{NO}$ \\
\hline 4 & $-1.376 \%$ & -0.183 & $\mathrm{NO}$ & 4 & $3.061 \%$ & 1.039 & $\mathrm{NO}$ \\
\hline 5 & $0.047 \%$ & 0.006 & $\mathrm{NO}$ & 5 & $0.859 \%$ & 0.292 & $\mathrm{NO}$ \\
\hline 6 & $-0.040 \%$ & -0.005 & $\mathrm{NO}$ & 6 & $0.042 \%$ & 0.014 & $\mathrm{NO}$ \\
\hline 7 & $0.241 \%$ & 0.032 & $\mathrm{NO}$ & 7 & $1.096 \%$ & 0.372 & $\mathrm{NO}$ \\
\hline 8 & $0.907 \%$ & 0.121 & $\mathrm{NO}$ & 8 & $3.229 \%$ & 1.096 & $\mathrm{NO}$ \\
\hline 9 & $5.762 \%$ & 0.768 & $\mathrm{NO}$ & 9 & $1.728 \%$ & 0.587 & $\mathrm{NO}$ \\
\hline 10 & $6.440 \%$ & 0.859 & $\mathrm{NO}$ & 10 & $1.951 \%$ & 0.662 & $\mathrm{NO}$ \\
\hline
\end{tabular}

The daily abnormal returns (ARs) during the event window related to event 2 are detailed in Table 5. The ARs for DRC and BWE on the event day are $3.907 \%$ and $0.838 \%$, respectively, but they are not significant at the $5 \%$ significance level. The same holds good for the entire event window for DRC as its ARs are not significant on any of the days. However, on day -7 in the event window for BWE, there is a massive AR of $7.599 \%$ with a t-statistic value of 2.580, which indicates that the ARs of BWE could be obtained seven days before the event day. This causes a rejection of the null hypothesis that ARs are close to zero.

The behavior of the abnormal returns (ARs) for DRC and BWE during the event window related to event 3 is summarized in Table 6. The ARs for DRC and BWE are all insignificant at the $5 \%$ significance level. Therefore, it is unable to reject the null hypothesis of no significant ARs.

The behavior of the cumulative abnormal returns (CARs) around the events is presented in Table 7 . The results of the CARs are investigated in different event windows $(-10 ;+10),(-5 ;+5)$ and $(-1 ;+1)$. The CARs for events 1 and 3 are mostly negative in these event windows, but they are all statistically insignificant. This reflects that the market reacts negatively to the information related to events 1 and 3, but its impact is not significant. Thus, there is a lack of evidence to reject the null hypothesis of no significant CARs for events 1 and 3. 
Table 6. Event 3 - Abnormal Returns for DRC and BWE.

\begin{tabular}{|c|c|c|c|c|c|c|c|}
\hline \multicolumn{8}{|l|}{ EVENT 3} \\
\hline \multicolumn{4}{|l|}{ DRC } & \multicolumn{4}{|l|}{ BWE } \\
\hline $\begin{array}{c}\text { Date in } \\
\text { event study }\end{array}$ & AR & $\begin{array}{c}\text { t-statistics } \\
\text { of } A R\end{array}$ & Significance & $\begin{array}{c}\text { Date in } \\
\text { event study }\end{array}$ & AR & $\begin{array}{l}\text { t-statistics } \\
\text { of AR }\end{array}$ & Significance \\
\hline-10 & $6.302 \%$ & 0.695 & $\mathrm{NO}$ & -10 & $-1.220 \%$ & -0.532 & $\mathrm{NO}$ \\
\hline-9 & $5.910 \%$ & 0.652 & $\mathrm{NO}$ & -9 & $2.154 \%$ & 0.939 & $\mathrm{NO}$ \\
\hline-8 & $3.899 \%$ & 0.43 & $\mathrm{NO}$ & -8 & $-1.841 \%$ & -0.803 & $\mathrm{NO}$ \\
\hline-7 & $2.139 \%$ & 0.236 & $\mathrm{NO}$ & -7 & $-1.473 \%$ & -0.642 & $\mathrm{NO}$ \\
\hline-6 & $4.630 \%$ & 0.51 & $\mathrm{NO}$ & -6 & $3.951 \%$ & 1.723 & $\mathrm{NO}$ \\
\hline-5 & $2.610 \%$ & 0.288 & $\mathrm{NO}$ & -5 & $-1.901 \%$ & -0.829 & $\mathrm{NO}$ \\
\hline-4 & $3.819 \%$ & 0.421 & $\mathrm{NO}$ & -4 & $-1.962 \%$ & -0.855 & $\mathrm{NO}$ \\
\hline-3 & $2.036 \%$ & 0.224 & $\mathrm{NO}$ & -3 & $-0.755 \%$ & -0.329 & $\mathrm{NO}$ \\
\hline-2 & $-1.205 \%$ & -0.133 & $\mathrm{NO}$ & -2 & $0.885 \%$ & 0.386 & $\mathrm{NO}$ \\
\hline-1 & $-1.670 \%$ & -0.184 & $\mathrm{NO}$ & -1 & $-1.875 \%$ & -0.818 & $\mathrm{NO}$ \\
\hline $\mathrm{O}$ & $2.079 \%$ & 0.229 & $\mathrm{NO}$ & $\mathrm{O}$ & $-3.917 \%$ & -1.708 & $\mathrm{NO}$ \\
\hline 1 & $-10.263 \%$ & -1.132 & $\mathrm{NO}$ & 1 & $2.245 \%$ & 0.979 & $\mathrm{NO}$ \\
\hline 2 & $-2.209 \%$ & -0.244 & $\mathrm{NO}$ & 2 & $-1.204 \%$ & -0.525 & $\mathrm{NO}$ \\
\hline 3 & $-6.845 \%$ & -0.755 & $\mathrm{NO}$ & 3 & $1.037 \%$ & 0.452 & $\mathrm{NO}$ \\
\hline 4 & $-5.962 \%$ & -0.657 & $\mathrm{NO}$ & 4 & $1.057 \%$ & 0.461 & $\mathrm{NO}$ \\
\hline 5 & $-5.168 \%$ & -0.57 & $\mathrm{NO}$ & 5 & $-0.292 \%$ & -0.127 & $\mathrm{NO}$ \\
\hline 6 & $-5.925 \%$ & -0.653 & $\mathrm{NO}$ & 6 & $-0.328 \%$ & -0.143 & $\mathrm{NO}$ \\
\hline 7 & $-13.375 \%$ & -1.475 & $\mathrm{NO}$ & 7 & $0.177 \%$ & 0.077 & $\mathrm{NO}$ \\
\hline 8 & $-16.072 \%$ & -1.772 & $\mathrm{NO}$ & 8 & $0.790 \%$ & 0.344 & $\mathrm{NO}$ \\
\hline 9 & $-16.323 \%$ & -1.8 & $\mathrm{NO}$ & 9 & $-0.429 \%$ & -0.187 & $\mathrm{NO}$ \\
\hline 10 & $-16.229 \%$ & -1.789 & $\mathrm{NO}$ & 10 & $-1.484 \%$ & -0.647 & $\mathrm{NO}$ \\
\hline
\end{tabular}

Table 7. Cumulative Abnormal Returns for DRC and BWE

\begin{tabular}{|c|c|c|c|c|c|c|c|}
\hline \multicolumn{8}{|l|}{ EVENT 1} \\
\hline \multicolumn{4}{|l|}{ DRC } & \multicolumn{4}{|l|}{ BWE } \\
\hline Window & CAR & $\begin{array}{c}\text { t-statistics } \\
\text { of CAR } \\
\end{array}$ & Significance & Window & CAR & $\begin{array}{c}\text { t-statistics } \\
\text { of CAR } \\
\end{array}$ & Significance \\
\hline$(-10 ;+10)$ & $-20.805 \%$ & -1.481 & $\mathrm{NO}$ & $(-10 ;+10)$ & $-1.047 \%$ & -0.071 & $\mathrm{NO}$ \\
\hline$(-5 ;+5)$ & $-5.331 \%$ & -0.524 & $\mathrm{NO}$ & $(-5 ;+5)$ & $-1.653 \%$ & -0.156 & $\mathrm{NO}$ \\
\hline$(-1 ;+1)$ & $0.068 \%$ & 0.013 & $\mathrm{NO}$ & $(-1 ;+1)$ & $-4.029 \%$ & -0.726 & $\mathrm{NO}$ \\
\hline \multicolumn{8}{|l|}{ EVENT 2} \\
\hline \multicolumn{4}{|l|}{ DRC } & \multicolumn{4}{|l|}{ BWE } \\
\hline Window & CAR & $\begin{array}{c}\text { t-statistics } \\
\text { of CAR }\end{array}$ & Significance & Window & CAR & $\begin{array}{c}\text { t-statistics } \\
\text { of CAR }\end{array}$ & Significance \\
\hline$(-10 ;+10)$ & $89.526 \%$ & 2.604 & YES & $(-10 ;+10)$ & $17.277 \%$ & 1.280 & $\mathrm{NO}$ \\
\hline$(-5 ;+5)$ & $46.077 \%$ & 1.852 & $\mathrm{NO}$ & $(-5 ;+5)$ & $4.198 \%$ & 0.430 & $\mathrm{NO}$ \\
\hline$(-1 ;+1)$ & $10.680 \%$ & 0.822 & $\mathrm{NO}$ & $(-1 ;+1)$ & $1.921 \%$ & 0.377 & $\mathrm{NO}$ \\
\hline \multicolumn{8}{|l|}{ EVENT 3} \\
\hline \multicolumn{4}{|l|}{ DRC } & \multicolumn{4}{|l|}{ BWE } \\
\hline Window & CAR & $\begin{array}{c}\text { t-statistics } \\
\text { of CAR }\end{array}$ & Significance & Window & CAR & $\begin{array}{c}\text { t-statistics } \\
\text { of CAR }\end{array}$ & Significance \\
\hline$(-10 ;+10)$ & $-67.819 \%$ & -1.632 & $\mathrm{NO}$ & $(-10 ;+10)$ & $-6.384 \%$ & -0.608 & $\mathrm{NO}$ \\
\hline$(-5 ;+5)$ & $-22.777 \%$ & -0.757 & $\mathrm{NO}$ & $(-5 ;+5)$ & $-6.682 \%$ & -0.879 & $\mathrm{NO}$ \\
\hline$(-1 ;+1)$ & $-9.854 \%$ & -0.627 & $\mathrm{NO}$ & $(-1 ;+1)$ & $-3.547 \%$ & -0.893 & $\mathrm{NO}$ \\
\hline
\end{tabular}

On the other hand, the CARs for DRC and BWE for event 2 are all positive in all these different event windows. This denotes that the market reacts optimistically to the event. The CAR for DRC in the $(-10 ;+10)$ event window is $89.526 \%$, and its t-statistic value of 2.604 is much greater than the critical value of 1.96 . This could be explained by the continuous positive ARs for DRC from day -10 to day +2 , though the values are insignificant. This suggests that fears of an escalating trade war between the US and China and the issues of increasing exchange rates and a reduction in the expected profits of listed companies have significant positive effects on its CAR in the ($10 ;+10)$ event window. The significant CAR value for DRC in this event window results in the strong rejection of the null hypothesis of no significant CARs.

In summary, the statistical results proved that the ARs and CARs for DRC and BWE are greatly different from zero in some cases, so the null hypothesis of no significant ARs and CARs is rejected. This indicates that the HOSE market is not semi-strong form efficient.

\section{Implications and Conclusions}

Our empirical investigation on the HOSE reveals that the VN Index and the stock prices of a sample of randomly selected companies from 10 different listed sectors all satisfy the requirements of RW3. This finding implies that the increments are uncorrelated, but they are clearly neither independent nor identically distributed because their squared increments are correlated. This suggests that the HOSE is fairly efficient in the weak form and it would not be possible to accurately predict the price movement of the VN Index and the selected listed companies on the HOSE to earn consistent excess returns over a sustained period based on their historical price changes. This is a statistically significant result as it could imply that recent policies designed to improve market operations and efficiency have been effective.

With regard to semi-strong form market efficiency, however, the results show that significant abnormal returns could be gained six days or seven days before the event day, but no significant ARs happen on the actual 
event date. This emphasizes the fact that information is leaked to the market prior to the announcement day. As a result, the null hypothesis of no significant ARs cannot be accepted. Furthermore, according to the results of event 2 , the CAR for DRC in the event window of $(-10 ;+10)$ is $89.526 \%$, and its t-statistic value of 2.604 is much greater than the critical value of 1.96 . This leads to the rejection of the null hypothesis that CARs are close to zero. The investors incur significant abnormal returns and significant cumulative abnormal returns by trading the stocks. This finding implies that the HOSE is not yet capable of accurately, and at the corresponding time, incorporating the publicly available information into the stock prices, and thus fails to satisfy the requirements of a semi-strong form market efficiency. To remedy this shortcoming in market operations, a range of new policies designed to eliminate information leakages and enhance transmission of information are needed if the efficiency of this key emerging market is to be further improved.

\section{References}

Benninga, S. (2014). Financial modelling. Cambridge: Massachusetts Institute of Technology Press.

Brown, S. J., \& Warner, J. B. (1985). Using daily stock returns: The case of event studies. Journal of Financial Economics, 14 (1), 3-31.

Campbell, J. W., Lo, A. W., \& MacKinlay, A. C. (1997). The econometrics of financial markets. West Sussex, Princeton University Press.

Chow, K. V., \& Denning, K. C. (1993). A simple multiple variance ratio test. Journal of Econometrics, 58(3), 385-401. Available at: https://doi.org/10.1016/0304-4076(93)90051-6.

Do, T. T., Le, T. B., \& Nguyen, T. T. (2015). Stock-market efficiency in emerging markets: Evidence from vietnamese stock market. Paper presented at the Proceedings of the 7 th International Scientific Conference Finance and Performance of Firms in Science, Education and Practice. Zlín: Tomas Bata University.

Dong Loc, T., Lanjouw, G., \& Lensink, R. (2010). Stock-market efficiency in thin-trading markets: The case of the Vietnamese stock market. Applied Economics, 42(27), 3519-3532. Available at: https://doi.org/10.1080/00036840802167350.

Eryigit, C., \& Eryigit, M. (2019). The effect of sponsorship announcements on stock returns of sponsees. International Journal of Sport Finance, $14(3), 173-190$.

Gupta, R., Yang, J., \& Basu, P. K. (2014). Market efficiency in emerging economies-case of Vietnam. International Journal of Business and Globalisation, 13(1), 25-40. Available at: https://doi.org/10.1504/ijbg.2014.063392.

Ho Chi Minh Stock Exchange. (2018). Annual report 2018. Ho Chi Minh: Ho Chi Minh Stock Exchange.

Ho Chi Minh Stock Exchange. (2019). Annual report 2019: Establishing values. Ho Chi Minh: Ho Chi Minh Stock Exchange.

Huong, T. T., \& Thuy, T. T. (2016). Vietnam's securities market - 16 years of establishment and development (2000-2016). Nomura Journal of Asian Capital Markets, 1(1), $31-39$.

KB Securities Vietnam. (2019). Macro stock market report: vietnam Macro stock market outlook in 2h 2019. Hanoi: KB Securities Vietnam.

Lo, A. W., \& MacKinlay, A. C. (1988). Stock market prices do not follow random walks: Evidence from a simple specification test. The Review of Financial Studies, 1(1), 41-66.

Luu, C. T., Pham, C. H., \& Pham, L. (2016). Seasonality effect on the Vietnamese stock exchange. International Journal of Financial Research, $7(3), 28-40$.

MacKinlay, A. C. (1997). Event studies in economics and finance. Journal of Economic Literature, 35(1), 13-39.

Mann, B. J., \& Babbar, S. (2017). Stock price reaction around new product announcements: An event study. IUP Journal of Management Research, 16(3), 46-57.

OECD. (2019). Business insights on emerging markets 2019. Paris: OECD Development Centre, Paris.

Pham, T. N., Nguyen, V. M., \& Vo, D. H. (2018). The cross-section of expected stock returns: New evidence from an emerging market. Emerging Markets Finance and Trade, 54(15), 3566-3576. Available at: https://doi.org/10.1080/1540496x.2018.1433031.

Phan, K. C., \& Zhou, J. (2014). Market efficiency in emerging stock markets: A case study of the Vietnamese stock market. IOSR Journal of Business and Management, 16(4), 61-73.

Preiss, R. M. (2019). Vietnam's stocks offer long-term profits with status upgrades. Retrieved from: https://www.forbes.com/sites/rainermichaelpreiss/2019/04/05/vietnams-stocks-offer-long-term-profits-with-statusupgrades/\#66dcb6491c20 [Accessed 15th May 2020].

Shaik, M., \& Maheswaran, S. (2017). Market efficiency of ASEAN stock markets. Asian Economic and Financial Review, 7(2), $109-122$.

Stock, J. H., \& Watson, M. W. (2015). Introduction to econometrics. Essex: Pearson Education Limited.

The Government. (2018). Decree on guidelines for law on support for small and medium-sized enterprises (Decree No. 39/2018/ND-CP dated March 11, 2018). Hanoi: The Government of Socialist Republic of Vietnam.

The National Assembly. (2014). Law on enterprises No. 68/2014/QH13 dated November 26, 2014. Hanoi: The National Assembly of Socialist Republic of Vietnam.

The Prime Minister. (2012). Approving the scheme on "restructuring of the securities market and insurance companies" (Decision No. 1826/QD-TTg dated December 06, 2012). Hanoi: The Prime Minister of Socialist Republic of Vietnam.

The World Bank. (2019). Taking stock december 2019: finance in transition - Unlocking capital markets for Vietnam's future development. Hanoi: The World Bank.

Tran, Q. T., \& Mai, Y. D. (2015). Stock market reaction to dividend announcements from a special institutional environment of vietnamese stock market. International Journal of Economics and Finance, 7(9), 50-58.

Tran, T. X., Nguyen, T. P., \& Pham, T. M. (2016). Semi-strong form efficiency: Market reaction to dividend and earnings announcements in Vietnam stock Exchange. Review of Business and Economics Studies, 4(3), 53-67.

Vo, X. V., \& Truong, Q. B. (2018). Does momentum work? Evidence from Vietnam stock market. Journal of Behavioral and Experimental Finance, 10, 10-15. Available at: https://doi.org/10.1016/j.jbef.2017.12.002.

Wright, J. H. (2000). Alternative variance-ratio tests using ranks and signs. Journal of Business छ Economic Statistics, 18(1), 1-9. Available at: https://doi.org/10.2307/1392131. 


\section{Appendix}

The joint and individual null hypotheses are rejected based on the Chow-Denning test, the Lo-MacKinlay test and the Wald test under homoscedasticity (see Tables A1, A2 \& A3). Under heteroscedasticity, the joint and individual null hypotheses of a martingale could not be rejected based on the Chow-Denning test and the LoMacKinlay test (see Tables A1 \& A2).

Table A1. Single variance ratio test on $\log \mathrm{P}_{\mathrm{t}}(\mathrm{VN}$ Index $)$.

Null Hypothesis: Log PT is a random walk

Date: 03/31/20 Time: 14:17

Sample: 1/02/2018 12/31/2019

Included observations: 497 (after adjustments)

Standard error estimates assume no heteroscedasticity

Use biased variance estimates

User-specified lags: 25102030

\begin{tabular}{|c|c|c|c|c|}
\hline \multicolumn{2}{|c|}{ Joint Tests } & Value & df & Probability \\
\hline \multicolumn{2}{|c|}{\begin{tabular}{l|l|l}
$\operatorname{Max}$ & $\mathrm{z}$ & $(\text { at period } 5)^{*}$
\end{tabular}} & 2.051586 & 497 & 0.1855 \\
\hline \multicolumn{2}{|c|}{ Wald (Chi-Square) } & 13.51411 & 5 & 0.0190 \\
\hline \multicolumn{5}{|c|}{ Individual Tests } \\
\hline Period & Var. Ratio & Std. Error & z-Statistic & Probability \\
\hline 2 & 1.000700 & 0.044856 & 0.015608 & 0.9875 \\
\hline 5 & 1.201619 & 0.098275 & 2.051586 & 0.0402 \\
\hline 10 & 1.170853 & 0.151452 & 1.128102 & 0.2593 \\
\hline 20 & 1.038178 & 0.222931 & 0.171253 & 0.8640 \\
\hline 30 & 0.992365 & 0.276593 & -0.027605 & 0.9780 \\
\hline
\end{tabular}

* Probability approximation using studentized maximum modulus with parameter value 5 and infinite degrees of freedom Test Details (Mean $=-7.15338111347 \mathrm{e}-05)$

\begin{tabular}{c|c|c|c|l}
\hline Period & Variance & Var. Ratio & Obs. & \\
\hline 1 & 0.00012 & -- & 497 & \\
\hline 2 & 0.00012 & 1.00070 & 496 & \\
\hline 5 & 0.00015 & 1.20162 & 493 & \\
\hline 10 & 0.00014 & 1.17085 & 488 & \\
\hline 20 & 0.00013 & 1.03818 & 478 & \\
\hline 30 & 0.00012 & 0.99236 & 468 & \\
\hline
\end{tabular}

Table A2. Multiple variance ratio test on $\log \mathrm{P}_{t}$ (VN Index).

Null Hypothesis: Log PT is a martingale

Date: 03/31/20 Time: 14:17

Sample: 1/02/2018 12/31/2019

Included observations: 497 (after adjustments)

Heteroscedasticity robust standard error estimates

Use biased variance estimates

User-specified lags: 25102030

\begin{tabular}{|c|c|c|c|c|}
\hline \multicolumn{2}{|c|}{ Joint Tests } & Value & df & Probability \\
\hline \begin{tabular}{l|l|l} 
Max & $\mathrm{z}$ & ( \\
\end{tabular} & eriod 5$)^{*}$ & 1.390532 & 497 & 0.5925 \\
\hline \multicolumn{5}{|c|}{ Individual Tests } \\
\hline Period & Var. Ratio & Std. Error & z-Statistic & Probability \\
\hline 2 & 1.000700 & 0.067692 & 0.010342 & 0.9917 \\
\hline 5 & 1.201619 & 0.144994 & 1.390532 & 0.1644 \\
\hline 10 & 1.170853 & 0.214893 & 0.795062 & 0.4266 \\
\hline 20 & 1.038178 & 0.304677 & 0.125305 & 0.9003 \\
\hline 30 & 0.992365 & 0.367704 & -0.020765 & 0.9834 \\
\hline
\end{tabular}

* Probability approximation using studentized maximum modulus with parameter value 5 and infinite degrees of freedom

Test Details (Mean $=-7.15338111347 \mathrm{e}-05$ )

\begin{tabular}{c|c|c|c|l} 
Test Details $($ Mean $=-7.15338111347 \mathrm{e}-05)$ & \\
\hline Period & Variance & Var. Ratio & Obs. & \\
\hline 1 & 0.00012 & -- & 497 & \\
\hline 2 & 0.00012 & 1.00070 & 496 & \\
\hline 5 & 0.00015 & 1.20162 & 493 & \\
\hline 10 & 0.00014 & 1.17085 & 488 & \\
\hline 20 & 0.00013 & 1.03818 & 478 & \\
\hline 30 & 0.00012 & 0.99236 & 468 & \\
\hline
\end{tabular}


Table A3. Rank variance ratio test on $\log \mathrm{P}_{\mathrm{t}}$ (VN Index).

\begin{tabular}{|c|c|c|c|c|}
\hline \multicolumn{5}{|c|}{ Null Hypothesis: Log PT is a random walk } \\
\hline \multicolumn{5}{|c|}{ Date: 03/31/20 Time: $14: 18$} \\
\hline \multicolumn{5}{|c|}{ Sample: 1/02/2018 12/31/2019 } \\
\hline \multicolumn{5}{|c|}{ Included observations: 497 (after adjustments) } \\
\hline \multicolumn{5}{|c|}{ Standard error estimates assume no heteroscedasticity } \\
\hline \multicolumn{5}{|c|}{ User-specified lags: 25102030} \\
\hline \multicolumn{5}{|c|}{$\begin{array}{l}\text { Test probabilities computed using permutation bootstrap: reps }=5000, \mathrm{rng}= \\
\mathrm{kn} \text {, seed }=1000\end{array}$} \\
\hline \multicolumn{2}{|c|}{ Joint Tests } & Value & df & Probability \\
\hline \multicolumn{2}{|c|}{$\operatorname{Max}|z|($ at period 5$)$} & 1.793294 & 497 & 0.1778 \\
\hline \multicolumn{2}{|c|}{ Wald (Chi-Square) } & 6.430104 & 5 & 0.2664 \\
\hline \multicolumn{5}{|c|}{ Individual Tests } \\
\hline Period & Var. Ratio & Std. Error & z-Statistic & Probability \\
\hline 2 & 1.019309 & 0.044856 & 0.430472 & 0.6778 \\
\hline 5 & 1.176236 & 0.098275 & 1.793294 & 0.0674 \\
\hline 10 & 1.194238 & 0.151452 & 1.282507 & 0.2010 \\
\hline 20 & 1.167488 & 0.222931 & 0.751298 & 0.4838 \\
\hline 30 & 1.096058 & 0.276593 & 0.347291 & 0.7580 \\
\hline \multicolumn{5}{|c|}{ Test Details (Mean $=0$ ) } \\
\hline Period & Variance & Var. Ratio & Obs. & \\
\hline 1 & 1.00000 & -- & 497 & \\
\hline 2 & 1.01931 & 1.01931 & 496 & \\
\hline 5 & 1.17624 & 1.17624 & 493 & \\
\hline 10 & 1.19424 & 1.19424 & 488 & \\
\hline 20 & 1.16749 & 1.16749 & 478 & \\
\hline 30 & 1.09606 & 1.09606 & 468 & \\
\hline
\end{tabular}

This table summarizes the statistical test results in all joint null hypothesis tests. The probability approximation in the Chow-Denning test is conducted using a studentized maximum modulus with a parameter value of 5 and infinite degrees of freedom.

Appendix 3. Statistical results of joint null hypothesis tests.

\begin{tabular}{|c|c|c|c|c|c|c|}
\hline \multirow{3}{*}{ No. } & \multirow{3}{*}{$\begin{array}{l}\text { Market } \\
\text { index/ } \\
\text { Company } \\
\text { Code }\end{array}$} & \multicolumn{2}{|c|}{$\begin{array}{l}\text { Homoscedastic Random Walk } \\
\text { Hypothesis (RW } 1)\end{array}$} & \multirow{2}{*}{$\begin{array}{l}\text { Conditional } \\
\text { Heteroscedastic } \\
\text { Random Walk } \\
\text { Hypothesis (RW3) } \\
\text { Joint Null } \\
\text { Hypothesis }\end{array}$} & \multirow{2}{*}{\multicolumn{2}{|c|}{$\begin{array}{l}\text { Wright's Rank Variance } \\
\text { Ratio Tests } \\
\text { Joint Null Hypothesis }\end{array}$}} \\
\hline & & \multicolumn{2}{|c|}{ Joint Null Hypothesis } & & & \\
\hline & & $\begin{array}{lr}\text { Chow } & \& \\
\text { Denning } & \text { Test } \\
\left(\begin{array}{l}\text { Max }|z| \\
\text { period m) }\end{array}\right. & \text { at } \\
\end{array}$ & $\begin{array}{l}\text { Wald-type } \\
\text { Test (Chi- } \\
\text { Square) }\end{array}$ & $\begin{array}{l}\text { Chow \& Denning } \\
\text { Test (Max }|z| \text { at } \\
\text { period } \mathrm{m} \text { ) }\end{array}$ & $\begin{array}{lr}\text { Chow } & \& \\
\text { Denning } & \text { Test } \\
(\operatorname{Max}|z| & \text { at } \\
\text { period m) }\end{array}$ & $\begin{array}{l}\text { Wald-type } \\
\text { Test (Chi- } \\
\text { Square) }\end{array}$ \\
\hline 1 & VN Index & 2.051586 & 13.514110 & 1.390532 & 1.793294 & 6.43010 \\
\hline 2 & AAA & 1.518724 & 4.396357 & 1.175483 & 1.347282 & 4.42633 \\
\hline 3 & BWE & 0.728012 & 4.751010 & 0.688696 & 0.738522 & 4.96286 \\
\hline 4 & BSI & 1.685831 & 5.940855 & 1.394067 & 1.935761 & 7.26802 \\
\hline 5 & DAG & 1.328480 & 4.299466 & 1.172319 & 1.671795 & 7.91515 \\
\hline 6 & DGW & 1.060222 & 1.772857 & 0.854374 & 1.223552 & 3.09841 \\
\hline 7 & DBD & 0.891214 & 2.702539 & 0.663286 & 1.437285 & 3.03724 \\
\hline 8 & DRC & 1.335389 & 4.690794 & 1.235332 & 1.450079 & 4.21442 \\
\hline 9 & PLX & 1.509040 & 7.136878 & 1.076068 & 1.637842 & 4.17150 \\
\hline 10 & $\mathrm{SAB}$ & 1.952080 & 4.402822 & 1.164296 & 2.037932 & 4.81433 \\
\hline 11 & SCR & 1.269829 & 9.310069 & 0.908594 & 1.205051 & 3.82641 \\
\hline \multicolumn{2}{|c|}{ No. of rejected nulls } & 1 & 10 & $\mathrm{O}$ & 1 & 11 \\
\hline
\end{tabular}

